\title{
Mirror image properties in human languages
}

\author{
IRENEUSZ KidA \\ Uniwersytet Śląski w Katowicach; Akademia Techniczno-Humanistyczna, Wydziat \\ Humanistyczno-Społeczny, Ul.Willowa 2,PL-43-309Bielsko-Biała,irekkida@yahoo.com
}

\begin{abstract}
Avtor na podlagi primerov iz angleščine, poljščine, malajščine, gotščine, latinščine in klasične grščine razpravlja o lastnostih zrcalnih podob v človeških jezikih. Kljub upoštevanju omejenega števila jezikov ugotavlja, da je lastnost zrcalne podobe značilnost vseh jezikov sveta. Razprava, ki se začenja $\mathrm{z}$ opisom naravnega pojava zrcalne slike in se nadaljuje $\mathrm{z}$ opazovanjem tega pojava $\mathrm{v}$ jeziku, prikazuje lastnosti zrcalne podobe na primeru stavkov, podvojitev in palindromov.
\end{abstract}

In this paper I discuss the phenomenon of mirror image properties in human languages. I give examples from English, Polish, Malay, Gothic, Latin and Classical Greek. Although I take into consideration only a few languages, my paper has further implications, namely, that mirror image properties exist in any language of the world. I start with a description of the natural phenomenon of mirror image and then extend my discussion to language. I talk about mirror image sentences, reduplication, and palindromes.

Ključne besede: zrcalna podoba, simetrija, soodvisnost, podvojitev, palindrom

Key words: mirror image, symmetry, interdependence, reduplication, palindromes

\section{Introduction}

People use mirrors every day. Any smooth surface that reflects light rays, rather than absorbs them, is a mirror. Most mirrors are made of a pane of glass that is coated, or silvered, on the back side so that the light cannot pass through but is reflected. The amount of light reflected depends on the kind of material that reflects it, the angle at which the light strikes it, and how polished the 
surface is. The more a given mirror is polished, the more light it will be able to reflect. Nevertheless, even the best mirrors never reflect all the light that falls upon them. The reader is probably familiar with the view of a reflected stretch of riverbank landscape in the water. Moreover, the reader may also be familiar with such painters as Salomon van Ruysdael or Paul Signac. Salomon van Ruysdael, in his painting "River landscape with a ferry", and Paul Signac in his paintings "View of the Seine at Herblay" and "The Island of Lucas near Les Andelys" present us with trees reflected in the surface of the water. We seem to be part of the paintings but somewhat detached from the far bank of the river. Standing on the near bank of the river, we can see the trees and their reflection in the water. We have to deal with an unusual kind of symmetry where the line dividing the two identical parts, that is, the landscape and its reflected image, can be called the axes of symmetry. Moreover, the two parts, one being the reflected image of the other, are dependent upon each other and cannot be separated, unless we remove the water surface and thus are left with a bare piece of landscape. The idea of symmetry is used in geometry and architecture, and it can also be present in art, as we can see in Ruysdael's and Signac's pictures. Symmetry can also be found in language.

\section{Sentence interdependence as a mirror image property}

According to Chomsky (1972), in the English language there are many sentences that can be defined as mirror image sentences and in which there may be dependencies between words that are non-adjacent. It is possible to separate these interdependent words by means of a phrase or clause that contains another pair of non-adjacent words that are interdependent. Lyons (1975: 58) illustrates Chomsky's idea by the following example:

anyone who says that, is lying

In the above example there is a dependency between the words anyone and is lying. These words are separated by the simple clause who says that in which there is a dependency between the words who and says. Moreover, on the basis of the example we can easily construct more complex examples like this one:

anyone who says that people who deny that ... are wrong, is foolish

In this example we can observe dependencies between the words anyone and is foolish, and between the words people and are wrong. Moreover, in between the words that and are we can go on inserting a clause which itself contains non-adjacent interdependent words. Lyons says that the result of this will be a sentence with mirror image properties and it will have the form $a+b+c \ldots$ $x+y+z$. In this sentence there there is a relationship of dependency between the outermost elements ( $a$ and $z$ ), between the next outermost elements ( $b$ and y) and so on. 
Let us consider another example that will further illustrate the existence of mirror image properties in English. According to Chomsky (1972: 21/22/23), if we assume that $\mathrm{S} 1, \mathrm{~S} 2, \mathrm{~S} 3, \ldots$ and so on are declarative sentences, then we can obtain such English sentences as described below:

(i) If $S 1$, then $S 2$

(ii) Either $\mathrm{S3}$, or $\mathrm{S4}$

(iii) The car which $\mathrm{S} 5$, is too expensive

Chomsky claims that in (i) we cannot have or in place of then. Moreover, in (ii) we cannot have then in place of or. And finally, in (iii) we cannot have are in place of $i s$. In each of these sets there is a dependency between words on opposite sides of the comma, that is, between the words if - then, the words either - or, and the words car - is. In each case we can insert between the interdependent words a declarative sentence S1, S2, S5, and this declarative sentence may in fact be one of (i-iii). In this way if in (i) we take S1 as (ii), and S3 as (iii), we will obtain the following sentence:

If, either, (iii), or $S 4$, then $S 2$

and S5 in (iii) may again be one of the sentences of (i-iii). Let us now take the following data in order to illustrate the whole situation:

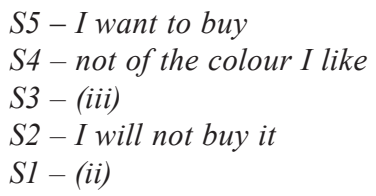

If we insert the above data into the sentences (i-iii), we will obtain the following:

(iii) The car which I want to buy, is too expensive

In this sentence the words the car and is are interrelated. Then we have another sentence:

(ii) Either the car which I want to buy is too expensive, or not of the colour I like

In this example, in turn, there is an interdependency between either and or. And finally, what is left is the following one:

(i) If, either the car which I want to buy is too expensive, or not of the colour I like, then I will not buy it

In this example the interdependence exists between the words if and then which, like the interdependent elements in the previous two sentences (ii) and (iii), are on opposite sides of the comma. In order to visualize the interdependency of the elements from example (i) let us have a look at the chart below:

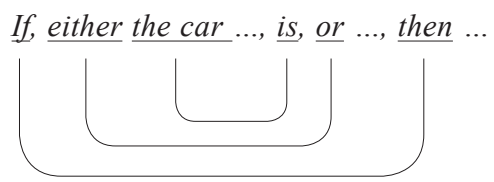


Chomsky (1972: 22) also says that "in English we can find a sequence $a+S 1$ $+b$, where there is a dependency between $a$ and $b$, and we can select as $S 1$ another sequence containing $c+S 2+d$, where there is a dependency between $c$ and $d$, then select as $S 2$ another sequence of this form, etc". Moreover, he claims that the possibilities for the construction of such sentences cannot be exhausted and the sentences constructed in this way will have mirror image properties; some of the sentences, however, will sound strange and artificial, but they will certainly be grammatical.

The combinations of the constituent elements may often be such that finding the dependencies that exist between them requires very close scrutiny, especially if the language where these dependencies occur is not our native language. Classical Greek, for example, can be a source of numerous examples of strange, if not eccentric, mirror image properties. Or perhaps instead of saying eccentric, it would be better to describe such sentences as centrifugal, as the interdependent elements of the sentence appear to fly outwards from the centre due to the action of some invisible centrifugal force. In order to illustrate that, let us take the following example:

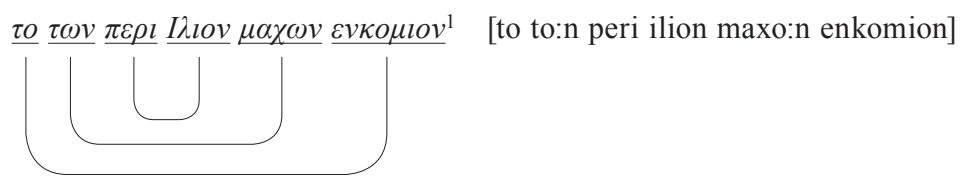

'The song of the battles of Troy'

The connecting lines are used to demonstrate which elements are interdependent. They are as follows:

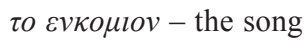

$$
\begin{aligned}
& \tau \omega v \mu \alpha \chi \omega v \text { - of the battles } \\
& \pi \varepsilon \rho \imath I \lambda \imath o v \text { - of Troy }
\end{aligned}
$$

The English literal translation of the above sentence would look something like:

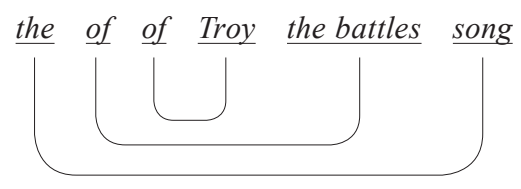

In the English version the sentence is completely incorrect and does not make sense. However, since Classical Greek was characterized by a rich inflectional system, sentences of this type could easily be constructed and the meaning conveyed. In Polish it would also be possible to construct a similar sentence but it would be somewhat awkward. Nevertheless, it would be understandable.

${ }^{1}$ I ignored the diacritic marks in the Greek example. 
Let us try to translate the Classical Greek sentence into Polish and see what it looks like:

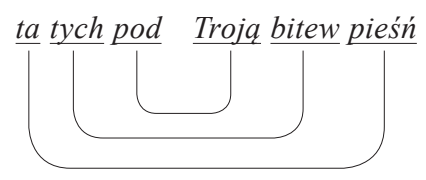

The interdependent constituents in this sentence are the following:

ta pieśn - this song

tych bitew - of the battles

pod Troja - of Troy

The Polish sentence is quite understandable because the Polish language still preserves much of the rich Indo-European inflectional system owing to which the construction of unusual, but understandable, structures is possible.

\section{Reduplication}

Another mirror image phenomenon in language is reduplication. Bussmann (1998) defines reduplication as follows: "doubling of initial syllables of a root or stem with or without a change in sound to express a syntactic category". An example of a syntactic category which comes into being in the process of reduplication is the formation of the Indo-European perfect tense; in Latin the perfect form of the verb tango "I touch" is tetigi "I touched", in Gothic the perfect form of the verb haitan "to be called" is haíhait "was called". The above forms are examples of reduplication with a change in sound. In order to see reduplication without the change in sound it is enough to take Malay for example. In this language, as Trask (1999) says, reduplication is employed for several purposes: adverb formation (baik "good", baik-baik "well), indefinite plurality (bunga "flower", bunga-bunga "flowers"), and word formation (mata "eye", mata-mata "policeman"). Similarly in Latin, reduplication serves different word formation purposes:

quo "where to?", quo-quo "wherever"
quot "how many?", quot-quot "whoever"
nequam "wicked", nequaquam "by no means"

As can be seen, reduplication is a common phenomenon in some languages of the world. It takes a variety of forms and serves a variety of purposes. The reduplicated forms are nothing else than mirror reflections of the base constituents. 


\section{Palindromes}

Finally, I would like to make reference to the occurrence of a strange phenomenon which exists in any language and which, as it seems, crops up unexpectedly and without premeditation or, if somebody is clever enough, after a conscious deliberation. What we mean are palindromes. The word palindrome comes from the Greek word palindromos which means "running back again". Bussmann (1998) defines the word palindrome as: "a term for a word or phrase that reads the same backwards and forwards". According to this definition the words Eva, Ada, Hanah, Otto, did, gag, moon, peep and radar are all palindromes. Moreover, even whole sentences can be palindromes. Let us take a few English Examples:

Able was I ere I saw Elba

Madam I'm Adam

Palindromes as long as a sentence exist also in Polish:

Kobyta ma maty bok

(Morawski 2008)

"The mare has a small side"

dat pan wina mało - wola pani tadna

tadna pani wola - mato wina pan dat

(Morawski 2009)

"The lord served little wine - the fair lady shouts

The fair lady shouts - the lord served little wine"

In all of the above examples we can insert an axis of symmetry and obtain two similar parts, one being a mirror reflection of the other, just as was the case with the river landscape reflected in the water.

\section{Ending}

To cap it all, we are surrounded by ubiquitous mirror images although we may not be fully aware of the fact. Mirror images exist in nature, language and anywhere else. Although in mirror images the two parts divided by the axis of symmetry seem to be identical, they are different in fact. They are identical superficially, but if one stops and thinks a little, one will notice that the reflected image is exactly the reverse of what it reflects. It is enough to look at a mirror for example. One may think that what one sees in the mirror is his face. But does not he see the very reverse of it? 


\section{REFERENCES}

H. BUSSMANN, 1998: Dictionary of language and linguistics. London: Routledge. N. CHOMSKY, 1972: Syntactic structures. The Hague: Mouton.

J. LYONS, 1975: Chomsky. Translated by Stanosz Barbara. Warszawa: Wiedza Powszechna.

T. MORAWSKI, 2008: Kobyła ma mały bok, czyli o polskich palindromach. Wydawca: Spółdzielnia »Rozrywka«.

T. MORAWSKI, 2009: Raz czart raz czar. Palindromy - czytaj tak albo wspak. Wydawnictwo SORUS.

R. L. TRASK, 1999: A dictionary of grammatical terms in linguistics. London: Routledge.

\section{Internet sources:}

http://www.paul-signac.org/

http://www.artcyclopedia.com/artists/ruysdael_salomon_van.html

\section{LASTNOSTI ZRCALNIH PODOB V ČLOVEŠKIH JEZIKIH}

Razprava je osredotočena na zrcalno sliko. Najprej avtor razpravlja o obstoju tega pojava v naravi, in sicer v vodi. Omenjenih je nekaj slik, ki predstavljajo zrcalno podobo. Potem razmišlja o obstoju zrcalne podobe v človeških jezikih. Ustavlja se ob stavkih, ki so lahko glede na svoje tvorbene značilnosti brezkončni, potem se osredotoča na podvojitve $\mathrm{v}$ različnih jezikih in na koncu opazuje še zrcalno podobo palindromov. $\mathrm{V}$ empiričnem delu so upoštevani različni jeziki, npr. angleščina, poljščina, gotščina, malajščina, latinščina in klasična grščina. Avtor zaključuje, da je zrcalna podoba univerzalna lastnost vseh jezikov. 